Case report

(C) Davirov Sh.M., Urinboev P.U., 2021

DOI 10.18019/1028-4427-2021-27-1-87-91

\title{
Repair of an open forearm fracture and extensive bony loss (case report)
}

\author{
Sh.M. Davirov ${ }^{1}$, P.U. Urinboev ${ }^{2}$ \\ ${ }^{1}$ Samarkand branch of the Republican Specialized Scientific and Practical Medical Center for Traumatology and Orthopedics, Samarkand, Uzbekistan \\ ${ }^{2}$ Samarkand State Medical Institute, Samarkand, Uzbekistan
}

\begin{abstract}
Introduction Repair of a double open comminuted fracture of forearm bones with extensive bony loss is challenging due to a high risk of infection and the need to address a significant bony defect. Neither internal fixation nor open reduction could be considered due to substantial bone loss and severely impaired circulation with a high risk of soft tissue necrosis and infection. We report staged management of forearm fracture using avascular autologous graft to repair the defect and maintain the forearm length. Objective Demonstrate the successful management of the double open comminuted fracture of forearm bones with extensive bony loss using Ilizarov external fixation, classical autologous grafting harvested from fibula and intramedullary (IM) nailing. Results and discussion The limb was temporarily fixed with Ilizarov frame in an extra-focal manner. An autogenous fibular graft of $11 \mathrm{~cm}$ was used to fill in the gap. Intramedullary nailing of the radius and ulna was produced and ulnar defect was repaired with autogenous fibular graft. IM nails were removed once the bones consolidated. The limb function was completely regained, anatomical length of the segment maintained and metal constructs removed. Conclusion Combination of different bone fixation modalities, classical autografting technique and intramedullary nailing provided complete recovery of the broken limb maintaining the function and bringing down the risk of complications to ensure a good clinical result.
\end{abstract}

Keywords: forearm injury, open fracture, bone loss, autograft, combined techniques

\section{INTRODUCTION}

With the successes achieved in modern traumatology and orthopedics, repair of extended circular defects of long bones following open comminuted fractures with extensive bone loss has the great medical and social impact for reconstructive surgery. There is an increasing number of patients who sustain injuries caused by accidents and may occur at home, work, or play to be treated with a variety of surgical options [1], with its advanatges and disadvantages. Difficulties in treatment of patients with open double comminuted forearm fractures with extensive bone defect are associated with an increased risk of pathological processes resulting from mechanical damage and infection of open wounds necessitating restoration of lost integrity between the proximal and distal radius and ulna with significant bone loss. Soft tissue injury is reported to range from 18.0 to $44.1 \%$ in bone fractures [2, 3]. According to the data from the A.V. Sklifosovsky Research Institute of Emergency Medicine, open fractures are complicated by osteomyelitis in $5.9 \%$ of cases with the prevalence increasing to $61 \%$ in combined, multiple injuries [4]. Osteomyelitis can result from open fractures of long bones, surgical treatment of closed fractures at a short term with the occurrence ranging between 5.3 and $75.4 \%$ as a consequence of open fractures [5].

Neither internal fixation nor open reduction could be considered due to substantial bone loss and severely impaired circulation with a high risk of soft tissue necrosis and infection. Different technologies are employed to repair bone defects [5-8] including the Ilizarov method [1, 5 9, 10, 11], fibula transfer [12], replantation of vascularized or free non-vascularized autograft at the gap [13], interlocking intramedullary nailing [14].

Distraction osteogenesis, which involves gradual lengthening of the proximal and the distal portions of bone or two bone fragments at a time [11], has many advantages avoiding morbidity at donor sites and ensuring reduced surgical and infectious risk. However, the duration of osteogenesis in extensive bone defects, in particular, wishes of the patient can necessitate use of other surgical modalities and 
their combination. The preferred option is to use the patient's own tissues to fill a large bone defect, and fibula is widely used as an autograft $[1,12$, 13]. Distraction osteogenesis, non-free bone graft and Ilizarov external fixation, replantation of a vascularized or free autograft into the defect site are considered biological methods of defect replacement and require long-term treatment and meticulous attention to the in-patient that might be difficult to perform in outpatient settings for people living in remote areas. Therefore, distraction osteogenesis can be combined with interlocking intramedullary nailing, autotransplantation and their combination to provide high-quality treatment and save time. In addition to that, patients might be reluctant to have foreign bodies, implants in the bones, or experience discomfort from some methods of treatment offered.

Objective Demonstrate the successful management of the double open comminuted fracture of forearm bones with extensive bony loss using Ilizarov external fixation, classical autologous grafting harvested from fibula and intramedullary (IM) nailing.

\section{MATERIAL AND METHODS}

Patient Z.M., born 1989, sustained an injury falling from height. Physical and radiological examination revealed an open double comminuted fracture of forearm bones, extensive defect of the ulnar diaphysis measuring more than $9 \mathrm{~cm}$ Gustilo and Anderson classification of open fractures grade II (Fig. 1).

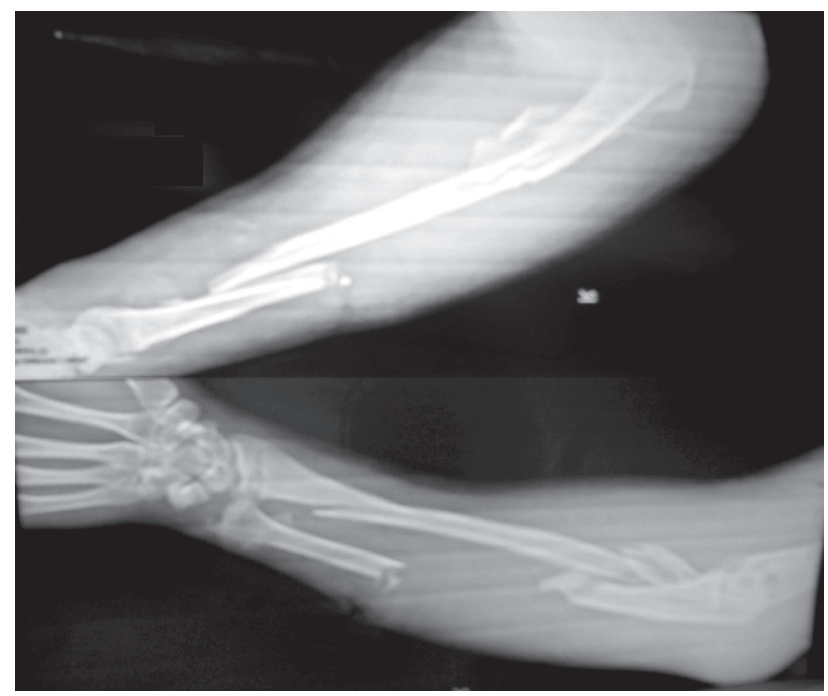

Fig. 1 Preoperative radiographs of the right forearm of patient Z.M.

Extrafocal external fixation of forearm bones with the Ilizarov apparatus was produced at the first stage (Fig. 2) without addressing the defect using the known technique [11]. Minimally invasive closed reduction of the radius and ulna was produced with Ilizarov rings and wires with normal anatomical length of the segment regained and the longitudinal axis of the limb realigned. Surgical debridement of the soft tissue wound was performed. The patient could ambulate and was followed up. The limb was fixed with the frame on for 5 weeks to allow wound healing.

Infection was arrested with antibiotics administered with laboratory tests being available with first signs of infected wound detected. The second stage of treatment was initiated after six weeks with the soft tissue wound healed using an avascular fibular autograft to repair ulnar defect with the classical method $[8,16]$. Fibular autografting involved no blood vessel transplants. Approximately an $11 \mathrm{~cm}$ section of fibula was carefully dissected free (Fig. 3) taking care of muscles. The periosteum and muscle portions were attached to the bone at a larger graft surface.

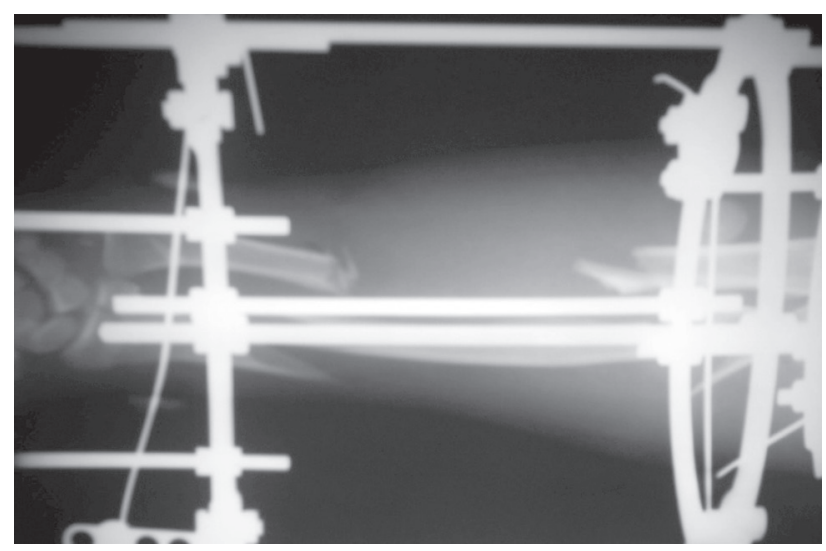

Fig. 2 Radiographs of the right forearm with frame applied to the upper limb

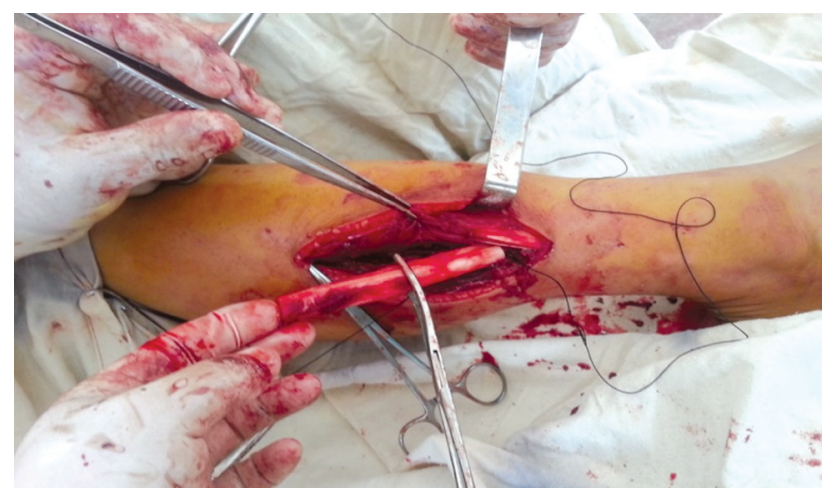

Fig. 3 Photograph showing harvesting procedure

The fracture site was exposed with a longitudinal incision over the ulnar defect with the bone ends being properly debrided. The bone being in contact with the graft was debrided, refreshed to bleeding to 
improve nutrition to the autograft. A bed was made to allow the avascular autograft in. A smooth Bogdanov pin, which was available and fitted for the patient, was used to fix the autograft and provide mechanical alignment of the proximal and distal ulna. The pin was inserted in a retrograde manner through the olecranon into the intramedullary canal of the autograft and the distal ulna. Wire fixation was produced and stable fixation of the ulna and the autograft was secured with intramedullary nail, and the Ilizarov device was removed. Intramedullary nailing provided fixation of the forearm bones and fibular graft at the defect site. Smooth wires that were available and fitted the patient were used for the case.

Open intramedullary osteosynthesis of the radius was performed with two smooth elastic wires. The fracture site was exposed using two incisions with wires being inserted into the intramedullary canal through the radiocarpal joint, and the radius reduced. Double oblique fractures of the radial shaft were additionally fixed with cerclage sutures and IM nail in place to ensure stabilization and mechanical strength to the bone. A short transverse wire was placed in the distal metaphyses of the radius and ulna to prevent displacement. The patient was followed up with IM nail and wire fixation performed for 22 months with appropriate radiological control. A radiograph made at 22-month follow-up of the second stage of treatment (Fig. 4) showed healing of the bone and the autograft with signs of inflammation at the olecranon around the Bogdanov IM nail. The metal constructs were removed through mini-incisions with bone fusion confirmed radiologically and the limb function recovered according to the physical examination and functional tests. The patient also wanted to have IM nails and wires removed. With all the metal constructs removed the patient could maintain bone consolidation radiologically. The patient stayed at the hospital for one week, showed maintained limb function and was seen at follow-up visits.

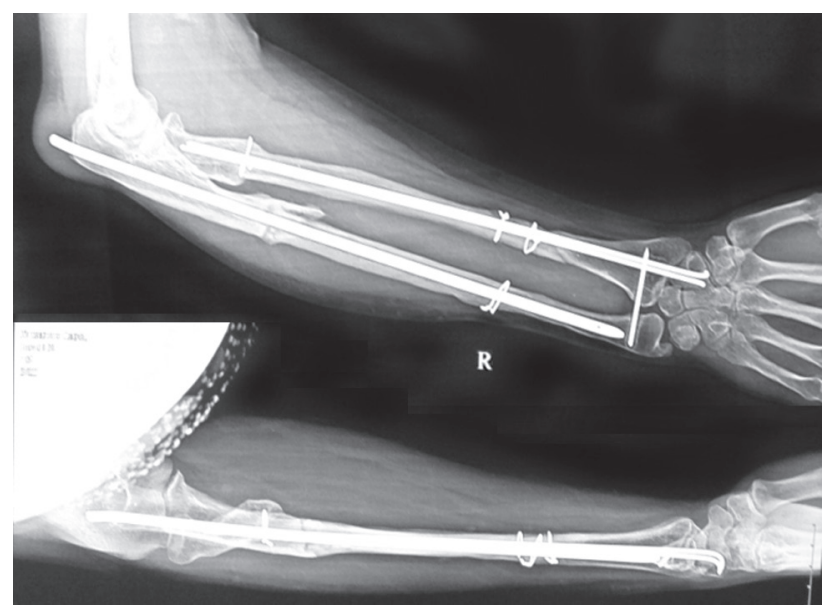

Fig. 4 Radiographs of the right forearm showing forearm bone fixation with IM nails

\section{RESULTS}

The multi-stage treatment of the patient with a forearm fracture using extra-focal external fixation at the acute period of injury followed by subsequent replacement of the bone defect with fibular autograft combined with IM nailing and wiring allowed us obtain the completely restored limb function. Anatomical length of the segment was maintained and all fixation constructs removed (Fig. 5).
Clinical assessment was produced with the elbow surgery score (Richards R. R. et al., 1994) to identify range of motion in the elbow, joint condition, pain, hand strength and the extent of daily activity. A healthy elbow joint on this scale gets the maximum score (100 points). The patient's elbow scored 70 at a 24-month follow-up [17] and she showed full wrist and elbow function (Fig. 6).

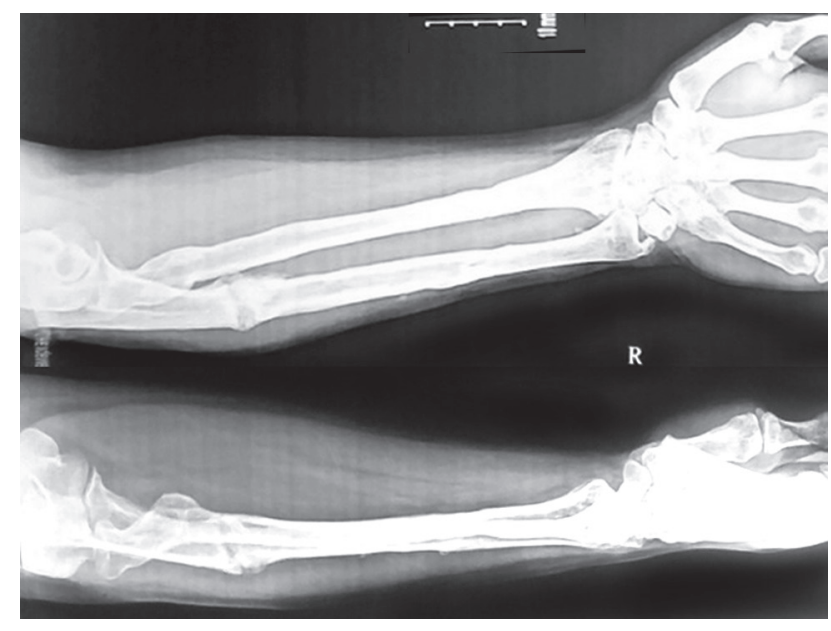

Fig. 5 Radiographs of the right forearm at a one-year follow-up 

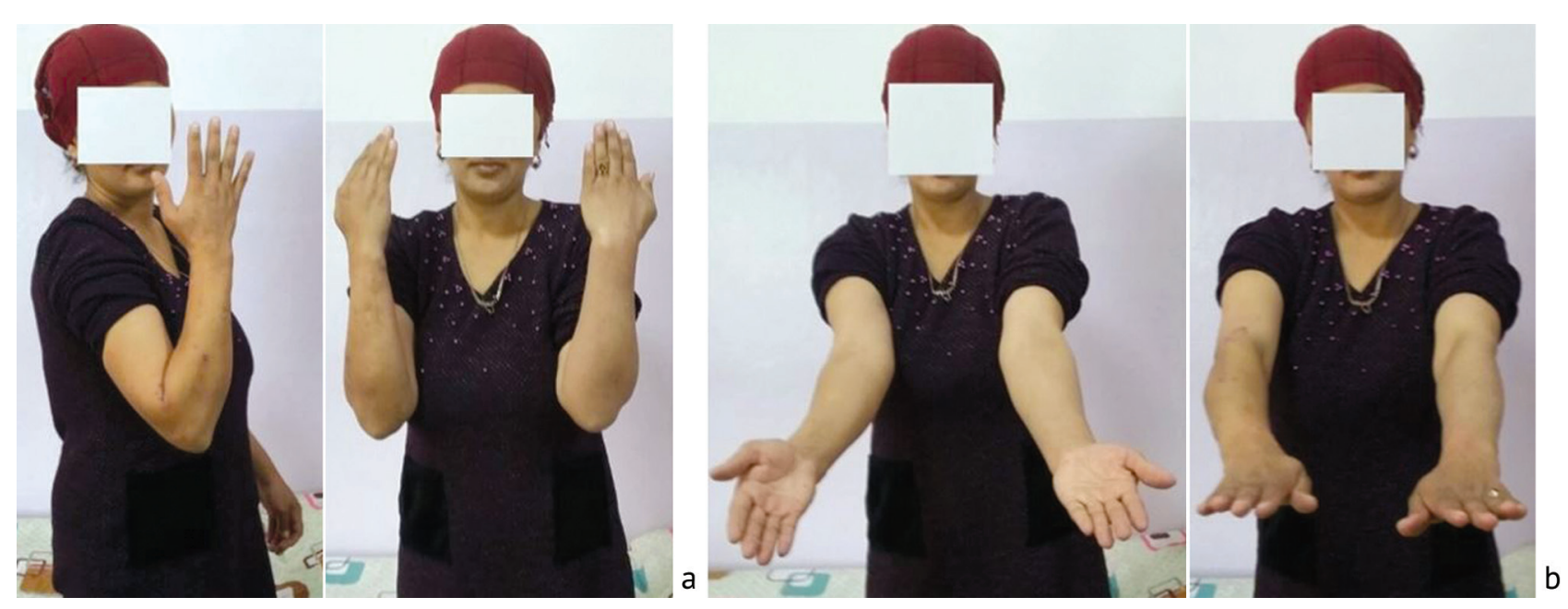

Fig. 6 The patient's limb function at one-year follow-up with metal constructs removed showing $(\boldsymbol{a})$ elbow flexion; $(\boldsymbol{b})$ supination and pronation of the hand

\section{DISCUSSION}

Extra-focal or intramedullary osteosynthesis can be the method of choice for open fractures of the forearm bones depending on the nature of injury. Fibular graft is normally used to repair extensive bone defects. However, long-term external fixation of the graft or the regenerate bone can lead to contractures of the adjacent joints and impaired limb function. In addition to that, the timing of distraction osteogenesis cannot be always acceptable for both the patient and the health care system. Intramedullary nailing or wiring used early after bone injury with extensive soft tissue wounds, primary bacterial contamination, comminution can be associated with infectious complications, suppuration and necrosis. A variety of surgical options can be attempted for one patient employing different modalities and their combinations to achieve an optimal outcome.
Compared to plaster cast immobilization, external fixation device provides effective immobilization of the limb allowing treatment and control of wound healing. Humerus and forearm bone defect can be successfully repaired with fibular grafting allowing reliable replacement of bone loss. The use of massive avascular grafts is reported to be associated with the risk of re-infection, long-term structural adjustment and osteolysis [18]. This clinical instance demonstrates the possibility of using an autograft without a vascular pedicle performing anastomosis in the patient with a large ulnar defect. The use of intramedullary fixation allows the patient reduce the time for constrained limb position, reduce risk of contractures, initiate early motion maintaining limb function.

\section{CONCLUSION}

Combination of external and internal bone fixation, autografting was shown to provide a complete recovery of the broken forearm bones resulting from an open comminuted fractrure of both bones with extensive bone defect exhibiting a good clinical outcome.

\section{REFERENCES}

1. Mauffrey C., Barlow B.T., Smith W. Management of segmental bone defects. J. Am. Acad. Orthop. Surg., 2015, vol. 23, no. 3, pp. 143-153. DOI: 10.5435/JAAOS-D-14-00018

2. Zhounousov E.T., Baimagambetov Sh.A., Botayev P.C. Klassifikatsii otkrytykh perelomov dlinnykh kostei [Classifications of open fractures of long bones]. Genij Ortopedii, 2005, no. 3, pp. 106-113. (in Russian)

3. Andreeva T.M. Travmatizm v Rossiiskoi Federatsii na osnove dannykh statistiki [Traumatism in the Russian Federation based on statistics]. Sotsialnye Aspekty Zdorovia Naseleniia, 2010, no. 4 (16), pp. 1-10. (in Russian)

4. Khasanov A.G., Nurtdinov M.A., Nigmatzianov S.S., Sakaev R.Sh., Karamova R.F. Opyt primeneniia plazmennykh potokov v kompleksnom lechenii khronicheskogo osteomielita (s kommentariem) [Experience of using plasma flows in the complex treatment of chronic osteomyelitis (with commentary)]. Khirurgiia. Zhurnal im. N.I. Pirogova, 2010, no. 10, pp. 59-61. (in Russian)

5. Kliushin N.M. Metod Ilizarova v gnoinoi osteologii [The Ilizarov method in purulent osteology]. Kurgan, PrintExpress, 2019,239 p. (in Russian)

6. Ilizarov G.A., Shved S.I., Martel I.I., compilers. Chreskostnyi osteosintez tiazhelykh otkrytykh perelomov kostei goleni: metod. rekomendatsii [Transosseous osteosynthesis of severe open fractures of the leg bones: guidelines]. Kurgan, VKNTs "VTO", 1990, 29 p. (in Russian) 
7. Martel I.I., Chevardin A.Iu. Transpozitsiia fragmentov malobertsovoi kosti po metodu Ilizarova v reabilitatsii postradavshikh $\mathrm{s}$ "ostrymi" defektami diafiza bolshebertsovoi [Transposition of the fibula fragments according to the Ilizarov method in the rehabilitation of injured persons with "acute" shaft defects of the tibia]. Genij Ortopedii, 2012, no. 1, pp. 5-10. (in Russian)

8. Barabash A.P., Kesov L.A., Barabash Iu.A., Shpiniak S.P. Zameshchenie obshirnykh diafizarnykh defektov dlinnykh kostei konechnostei [Filling the extensive shaft defects of limb long bones]. Travmatologiia i Ortopediia Rossii, 2014, no. 2, pp. 93-99. (in Russian)

9. Papacostidis C., Bhandari M., Giannoudis P.V. Distraction osteogenesis in the treatment of long bone defects of the lower limbs: effectiveness, complications and clinical results; a systematic review and meta-analysis. Bone Joint J., 2013, vol. 95-B, no. 12, pp. 1673-1680. DOI: 10.1302/0301-620X.95B12.32385

10.Rohilla R., Siwach K., Devgan A., Singh R., Wadhwani J., Ahmed N. Outcome of distraction osteogenesis by ring fixator in infected, large bone defects of tibia. J. Clin. Orthop. Trauma, 2016, vol. 7, no. Suppl. 2, pp. 201-209. DOI: 10.1016/j.jcot.2016.02.016

11.Ilizarov G.A. Osnovnye printsipy chreskostnogo kompressionnogo osteosinteza [Main principles of transosseous compression osteosynthesis]. Ortopediia, Travmatologiia i Protezirovanie, 1971, no. 11, pp. 7-15. (in Russian)

12.Anastasieva E.A., Sadovoi M.A., Voropaeva A.A., Kirilova I.A. Ispolzovanie auto- i allotrasplantatov dlia zameshcheniia kostnykh defektov pri rezektsiiakh opukholei kostei [The use of auto- and allografts in order to fill bone defects for bone tumor resections]. Travmatologiia i Ortopediia Rossii, 2017, vol. 23, no. 3, pp. 148-155. (in Russian)

13.Shevtsov V.I., Borzunov D.Y. Reabilitatsiia patsientov s defektami i lozhnymi sustavami dlinnykh kostei, sovremennoe sostoianie problemy [Rehabilitation of patients with long bone defects and pseudoarthroses, current state of the problem]. Genij Ortopedii, 2008, no. 4, pp. 48-54. (in Russian)

14.Grazhdanov K.A., Barabash A.P., Barabash A.Iu., Kauts O.A. Intramedulliarnyi osteosintez v lechenii posledstvii perelomov plechevoi kosti [Intramedullary osteosynthesis in the treatment of humeral fracture sequelae]. Saratovskii Nauchno-Meditsinskii Zhurnal, 2018, vol. 14, no. 3, pp. 523-529. (in Russian)

15.Kim P.H., Leopold S.S. Gustilo-Anderson Classification. Clin. Orthop. Relat. Res., 2012, vol. 470, no. 11, pp. 3270-3274. DOI: $10.1007 / \mathrm{s} 11999-012-2376-6$

16.Malikov M.Kh., Kurbanov U.A., Davlatov A.A. Peresadka vaskuliarizirovannykh kostnykh transplantatov pri travmaticheskikh defektakh i lozhnykh sustavakh kostei verkhnei konechnosti [Transplantation of vascularized bone grafts for traumatic defects and pseudoarthroses of the upper limb bones]. Novosti Khirurgii, 2012, vol. 20, no. 5, pp. 82-90. (in Russian)

17.Merkulov V.N., Dergachev D.A., Dorokhin A.I. Artroplastika pri lechenii posttravmaticheskikh kontraktur i ankilozov loktevogo sustava u detei [Arthroplasty in treatment of posttraumatic contractures and ankyloses of the elbow in children]. Detskaia Khirurgiia, 2014, vol. 18, no. 4, pp. 34-38. (in Russian)

18.Bagherifard A., Ghandhari H., Jabalameli M., Rahbar M., Hadi H., Moayedfar M., Sajadi M.M., Karimpour A. Autograft versus allograft reconstructions of acute tibial plateau fractures: a comparative study of complications and outcome. Eur. J. Orthop. Surg. Traumatol., 2017, vol. 27, no. 5, pp. 665-671. DOI: 10.1007/s00590-016-1863-y

Received: 11.05 .2020

\section{Information about the authors:}

1. Sharof M. Davirov, M.D.,

Samarkand branch of the Republican Specialized Scientific and Practical Medical Center for Traumatology and Orthopedics, Samarkand, Uzbekistan,

Email: sharofd1976@mail.ru

2. Payzulla U. Urinboev, M.D., Ph.D., Professor,

Samarkand State Medical Institute, Samarkand, Uzbekistan 